\title{
Jobs satisfaction mediates relationship between facets of job and citizenship behavior: a study of female employees of banking sector of Pakistan
}

\author{
Ishfaq Ahmed, Ahmad Usman, Sahar Latif Rana \\ Hailey College of Commerce, University of the Punjab Lahore, Pakistan \\ ishfakahmed@gmail.com
}

\begin{abstract}
Several articles have reported and discussed the job satisfaction and dissatisfaction of female workers in miscellaneous organizations. However, very few empirically-supported explanations have been given to explain how job satisfaction mediates the relationship between facets of job and citizenship behavior in banking sector of Pakistan and specially focusing on female employees. Probes into the explanations of determining how job satisfaction mediates the relationship between facets of job and citizenship behavior, the data were collected from female employees of banking sector of Pakistan. Total 200 self-administered questionnaires were distributed among the female staff of different banks. 188 completed questionnaire were received back with response rate of $94 \%$. The participation in survey was voluntary and confidentiality of responses was ensured. Statistical analysis reveals that there exists significant relationship between facets of job (pay, promotion, supervisor's behavior and coworker's behavior) and dependent variables (organizational citizenship behavior); likewise, job satisfaction mediates the relationship between facets of job and citizenship behavior. Limitations and future implementations of this research are also discussed.
\end{abstract}

Keywords: satisfaction, OCB, Pay, Promotion, Supervisor, Co-workers, mediation, banking sector

\section{Introduction}

The notion of job satisfaction prevailing in the organizations is as old as the jobs and organization itself are. History reveals the evidences regarding the importance of job satisfaction as described by the various managers and organizational researchers. Different researchers have different views about the level of job satisfaction. Like, Robbins, et al., (2004) stated that, "Job satisfaction is an employee's general attitude towards his or her job."It can be said that, "A happy worker is a productive worker" (Balser \& Harris 2008).Owing to the job satisfaction positive feelings emerge among the employees. Job satisfaction is beneficial for employees as well as for organizations such as, reduction in complaints, less employee turnover, increase in employee's performance as well as increase in organization's productivity (Igbaria\& Guimaraes, 1993).

A satisfied worker is more likely to be creative, innovative, and loyal. Efficientand effective workforce is an outcome of job satisfaction and it is a good indicator of permanence (Igbaria\& Guimaraes,1993).Job satisfaction is a multidimensional construct. It is poised of various facets or key essentials. Standardized scale for measuring job satisfaction includes the following rudiments: working environment, supervision, pay, promotional opportunities and relation with coworkers.

Various researchers in various working environments have studied Job satisfaction of female employees. Herbohn, (2005) found that women who were interested in acquiring higher education in the past decade now represents half of the graduates; During this time the involvement of these women into public accounting firms created a large promotional opportunities for women. While considering the Pakistani economy and organizational structures, it has been observed that females are one of the most neglected parts of our economy and the gender differences are prevailing at their apex level.

Female employees are devoid of all those rights, mentioned in international agreements to which Pakistan is a signatory. Since the birth of this nation, females have contributed largely towards its development. About one fifth of the Pakistan's GDP is generated from informal sector, which employed 20 million workers in total, out of which 12 million are female staff (Mustafa, 2011). So women are a big chunk of workforce in Pakistan. This research is an attempt to evaluate the job satisfaction level of female employees working in the Banking 
sector of Pakistan by considering the various facets of job satisfaction and in turn to evaluate the effect of job satisfaction on the citizenship behavior of those employees with their organizations

\section{Literature Review}

Job satisfaction is a multidimensional construct. It is made up of various facets or key elements. Standardized scale for measuring job satisfaction includes the following rudiments: working environment, supervision, pay, promotional opportunities and relation with coworkers. Beside these elements, various other variables also affect the level of satisfaction of employees. Job satisfaction index is used to measure the level of job satisfaction (Murphy, et al., 2002). Owing to this instrument, facets of the job satisfaction are Pay, Promotion, Reward and recognition, working conditions, Supervisors and Co-workers. Various researchers have identified various determinants of job satisfaction, ranging from organizational factors like organizational culture, reward system, support from management, promotion etc. to personal factors lime age, gender, qualifications, experience etc.

Organizational factors includes factors such as pay (Danish \& Usman, 2010; Okpara, 2006; Crossman\& Zaki, 2003; Smucker et al. 2003), organizational culture (Kwantes, 2009; Lund, 2003; Eskildsen, et al., 2010; Lok \& Crawford 2004),promotion (Danish and Usman, 2010; Ismail and Zakria, 2009; Smucker et al. 2003), relations with supervisor (Lee, 2008; Crossman\& Zaki 2003; Chen, 2001; Oshagbemi, 2000), relations with co-workers (Malik, et al, 2010; Smucker 2003). Personal factors such as, demographical traits have significant effect on satisfaction of employees (Bowen\&Cattell, 2008; Kavanaugh, et al., 2006; Lok\&Crawford, 2004; and Oshagbemi, 2003). This study focus on organizational factors like pay, promotion, relationship with supervisors, relationship with co-workers, and its impact on satisfaction and OCB of female employees of banking sector of Pakistan. Following sections cover literature on the variables and their relationships.

Pay, Promotion and Job satisfaction: Number of studies exists on the reward system and its impact on job satisfaction, but few studies are available on the salary differences among the male and female bank managers (Crossman\& Zaki 2003). Okpara (2006) opined that high level of job satisfaction exists in male mangers regarding the pay policies of their company, than their female counterparts. In the field of journalism, Smucker, et al., (2003) determined that female journalists were satisfied with their salaries but less promotional opportunities exists for them. According to testimonial given by Donohue\& Heywood (2004) females receive low salaries than male and this gender specific pay system is barriers to women's career progression and finally it contribute significantly to lower job satisfaction and he found no significant impact on satisfaction (Herbohn, 2005). Danish\& Usman, (2010) argued that pay and promotional opportunities have great impact on level of job satisfaction.Ismail\&Zakaria, (2009) illustrates that interactional justice, pay and promotion are directly and significantly related to job satisfaction.

Supervisors, Co-workers and job satisfaction: Another important factor about job satisfaction is relationship with superviosrs and co-workers. As noted by Oshagbemi (2000) satisfaction with supervisor's behavior is an important predictor of job satisfaction.Chen (2001) argued that supervisor's behavior has direct and significant relationship with level of job satisfaction. According to the research of Smucker, et al., (2003) females are satisfied with theirco workers and with supervisor's behavior, according to Crossman\& Zaki (2003) females have low level of job satisfaction with their supervisor's behavior as compared with their male colleagues. Malik et al., (2010) university teachers of Pakistan are satisfied with their co-workers, supervisor's behavior, and working conditions and with their organization's promotional opportunities. Lee (2008) found that subordinates are more satisfied with their supervisor's integrating compromising and obligating style and less satisfied with their dominating and avoiding style.

Job satisfaction and Organizational Citizenship Behavior: It would not be wrong to say that job satisfaction is a vital element of employees' citizenship behavior with their organizations. Murphy et al.(2002) Job satisfaction is positively, strongly and significantly correlated with organizational citizenship behavior. Gonza'lez, \& Garazo.(2006) employees OCB is positively affected by employee's level of job satisfaction. Kim (2006) found that the OCB is not positively and directly affected by job satisfaction whereasFoote \& Tang (2008) illustrates that the team commitment as a moderating variable positively influences the relationship existing between both organizational citizenship behavior and job satisfactions. 
Pay, Promotion and Organizational Citizenship Behavior: Farh, et al., (1997) found stronger relationship between justice (in rewards and promotion opportunities) and citizenship behavior for men than for women. Williams, et al., (2006) opined that strong relationship exists between pay level satisfaction and OCB. Hui et al., (2000) found thatemployees who were more likely to decline in their OCB after the promotion were those who perceived $\mathrm{OCB}$ as instrumental to their promotion and who were promoted. Those employees had lower salary increases and advanced more slowly who spent more time on OCB than those employees who spent less time on OCB(Bergero et al., 2011).

Supervisor's Behaivor, Co workers andOrganizational Citizenship Behavior: The trust in manager and trust in subordinates have direct and positive relationship with employee's citizenship behavior with his organization (Brower, et al., 2009). Konovsky\& Pugh (1994) opined that the relationship between employee citizenship and procedural fairness in the supervisor's decision-making is proposed to be mediated by employee's trust in a supervisor. Lam, et al., (1999) supervisors' behavior had greater impact on employees OCB than subordinates. Individuals OCB role definitions (i.e., the extent to which individuals define OCB as extra-role behavior) mediates the relationship between justice perceptions andOCB performance (Tepper\& Taylor, 2002).

Theoretical Framework: From the given literature, following research model and hypothesis can be formulated.

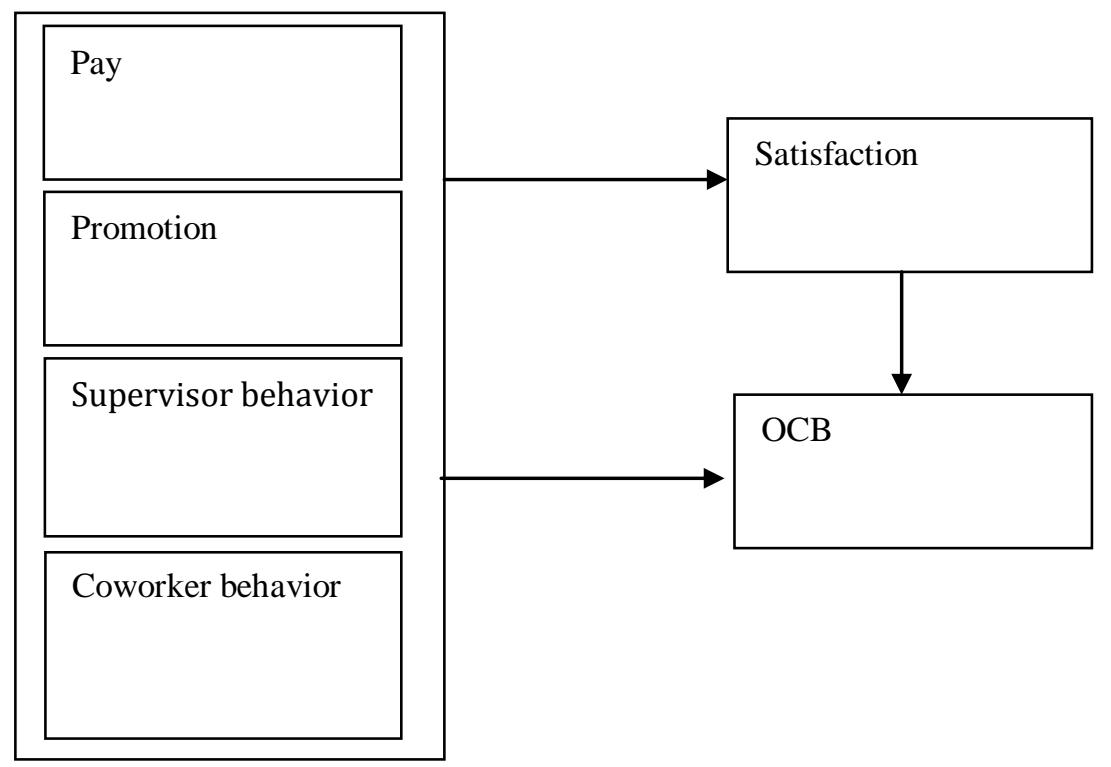

H1: Job satisfaction mediates relationship of pay and organizational citizenship behavior

H2: Job satisfaction mediates relationship of promotion and organizational citizenship behavior

H3: Job satisfaction mediates relationship of supervisor's support and organizational citizenship behavior

H4: Job satisfaction mediates relationship of coworkers' support and organizational citizenship behavior

\section{Methodology}

This study was conducted in banking sector of Pakistan. According to Dunya.com (2007) there are 55 Banks in total; these banks are categorized in the following manner; Public sector Bank ( 4 banks), Specialized Bank (4 banks), Private Banks (20 bansks), Islamic Banks ( 5 banks), Foreign Banks (7 banks), Micro Finance Banks (7 banks) and Development financial institution (8 banks). In order to keep a focus of the study banking sector was divided in three sectors i.e. Local state owned banks, local private banks and foreign banks. In the process of selection of banks, multistage sampling technique was used. In first stage of data collection, banks 
were divided in three stratums (public banks, private banks, and foreign banks). In second stage of sampling 8 banks were selected from these stratums using simple random sampling technique. In third stage of sampling, out of these banks 8 branches were selected randomly from where 200 employees were selected, on the basis of random sampling technique, for data collection. Questionnaire was used as a tool for data collection. Total 200 questionnaires were personally distributed. Out of total, 188 completely filled questionnaires were received back. SPSS 17.0 was used for data analysis.

\section{Results}

Average age of respondents is 28 years. While considering the division of organization; $47.3 \%$ belong to the foreign banks, 29.3 belong to Local private, and $23.4 \%$ belong to Local state owned banks. To analyze the responses descriptive statistics is used in which the mean and standard deviation of independent variables versus dependent variable is obtained. The findings are shown below in the table

$\underline{\text { Table-1 Descriptive Statistics }}$

\begin{tabular}{lll}
\hline & MEAN & STD. DEVIATION \\
\hline Job Satisfaction & 3.3245 & .72181 \\
Pay & 3.2500 & 1.02646 \\
Supervisor's behavior & 3.7213 & .70337 \\
Promotion & 3.4539 & .79713 \\
Co-workers & 3.7110 & .80980 \\
OCB & 3.5707 & .70583 \\
\hline
\end{tabular}

The table- 1 represents that the mean score of job satisfaction and pay are 3.3245 and 3.2500 respectively, very near to neutral. The mean score of these explained variables demonstrate that the respondents are neutral regarding their feelings about pay and job satisfaction. Mean score of promotion is 3.45 which shows that women employees are having neutral feelings about their promotion opportunities, neither they are happy nor they are disappointed with promotion. Whereas the score of supervisor's behavior, co-worker's behavior and OCB are 3.72, 3.71 and 3.57 respectively, it shows that the mean score are near to value of 4 on scale i.e. "satisfied", means respondents feelings about their supervisor, co-workers is positive and their Organizational citizenship behavior is also positive about their organization.

Table-2 Regression Analysis for testing hypothesis of mediation: The following table shows the series of regression equations used to test the mediating effect of job satisfaction between the various facets of job and organizational citizenship behavior.

To determine the mediating effect of job satisfaction between pay and organizational citizenship behavior, we examined equations $1 \mathrm{a}, 2 \mathrm{a}$ and $3 \mathrm{a}$. In equation one (1a), job satisfaction (mediator) was regressed on pay (predictor) and the relationship was significant $(B=.247, p<.01)$. In equation two $(2 a)$, OCB (the dependent variable) was regressed on pay (the predictor) and the relationship was found to be significant ( $\mathrm{B}=.454$, $\mathrm{p}<.01)$. In equation three (3a), OCB was simultaneously regressed on pay and job satisfaction. The relationship between OCB and Pay was significant $(B=0.406)$ but less than in equation two $(2 \mathrm{a})(\mathrm{B}=.454)$. Thus, it proves that job satisfaction is the significant mediator of the relationship between pays and organizational citizenship behavior.

To test the mediating effect of job satisfaction on the relationship between promotion and OCB, a series of three regression equations were used (equations $1 b, 2 b$ and $3 b$ in above Table). In the first equation (1b) job satisfaction was significantly $(B=.436, p<.01)$ related to promotion. In the second equation $(2 \mathrm{~b}) \mathrm{OCB}$ was regressed on promotion and the relationship was significant $(B=.269, \mathrm{p}<.01)$. In the third equation $(3 \mathrm{~b})$, job satisfaction and promotion were simultaneously regressed on OCB and there was significant relationship between promotion and OCB $(B=.171)$ but less than in equation two $(2 \mathrm{~b})(\mathrm{B}=.269)$. Hence, the study proved the mediating effect of job satisfaction between promotion and OCB. The mediating effect of job satisfaction between supervisors is examined by the equations (1c, 2c, and 3c). In the first equation (1c) job satisfaction was significantly $(B=.254, p<.01)$ related to supervisor's behavior. In the second equation $(2 \mathrm{c})$ OCB was 
regressed on supervisors and the relationship was significant $(B=.080, p<.01)$. In the third equation (3c), job satisfaction and supervisor's behavior were simultaneously regressed on OCB and there was significant relationship between supervisor's behavior and OCB $(B=.005)$ but less than in equation two $(2 \mathrm{~b})(\mathrm{B}=.080)$. Hence, the study proved the mediating effect of job satisfaction between promotion and OCB.

Table- 2 Test to find mediation relationship

\begin{tabular}{|c|c|c|c|c|c|c|c|}
\hline Eqn. & Dependent variable & $\begin{array}{l}\text { Independent } \\
\text { variable }\end{array}$ & Beta & $T$ & $\begin{array}{l}\text { R- } \\
\text { Square }\end{array}$ & $\mathbf{F}$ & $\mathbf{P}$ \\
\hline $1 \mathrm{a}$ & Job satisfaction & Pay & .247 & 3.473 & .056 & 12.064 & 0.001 \\
\hline $1 b$ & Job satisfaction & Promotion & .436 & 6.600 & .185 & 43.555 & 0.000 \\
\hline $1 \mathrm{c}$ & Job Satisfaction & Supervisors & .254 & 3.574 & 0.059 & 12.775 & 0.000 \\
\hline 1d & Job Satisfaction & Co workers & .174 & 2.417 & 0.025 & 5.842 & 0.017 \\
\hline $2 a$ & ОСВ & Pay & .454 & 6.956 & .206 & 48.390 & 0.000 \\
\hline $2 \mathbf{b}$ & OCB & Promotion & .269 & 3.802 & .067 & 14.457 & 0.000 \\
\hline $2 c$ & OCB & Supervisors & .080 & 1.097 & .001 & 1.204 & .274 \\
\hline $2 d$ & ОСВ & Co workers & .326 & 4.699 & .101 & 22.077 & .000 \\
\hline \multirow[t]{2}{*}{$3 a$} & OCB & Pay & .406 & 6.145 & .243 & 29.707 & .000 \\
\hline & & Job satisfaction & .198 & 2.992 & & & .003 \\
\hline \multirow[t]{2}{*}{$3 \mathbf{b}$} & OCB & Promotion & .171 & 2.228 & .112 & 11.713 & .027 \\
\hline & & Job satisfaction & .223 & 2.897 & & & .004 \\
\hline \multirow[t]{2}{*}{$3 c$} & OCB & Supervisors & .005 & .070 & 0.089 & 8.993 & .944 \\
\hline & & Job satisfaction & .296 & 4.084 & & & .000 \\
\hline \multirow[t]{2}{*}{ 3d } & OCB & Co workers & .282 & 4.141 & 0.166 & 18.398 & .000 \\
\hline & & Job satisfaction & .248 & 3.642 & & & .000 \\
\hline
\end{tabular}

Furthermore, the study tested the mediating effect of job satisfaction on the relationship between co-workers and OCB by examining equation $1 \mathrm{~d}, 2 \mathrm{~d}$, and $3 \mathrm{~d}$. The first equation (1d) demonstrated significant relationship $(B=.174, p<.01)$ between job satisfaction and co-workers. The second equation $(2 \mathrm{~d})$ demonstrated a significant relationship between OCB and co workers $(B=.326, p<.01)$. In equation three $(3 \mathrm{~d})$, co-workers and job satisfaction were simultaneously regressed on OCB. An examination of the beta coefficients reveals coworkers was stronger in the second equation $(B=0.326)$ than in the third equation $(B=0.282$,). Hence, the findings confirm that job satisfaction mediates the relationship between co-workers and OCB. 


\section{Conclusion}

The aim of the study was to explore the mediation effect of job satisfaction between various facets of job (pay, promotion, and supervisor's behavior and co workers) and Organizational citizenship behavior. Analysis has shown a significant relationship among all facets of job and job satisfaction, Job satisfaction and OCB and between facets of job and OCB. This proves that pay, promotion, role played by supervisors and role played by co-workers are important determinants of job satisfaction and OCB. In addition, satisfaction of employees moderates relationship between job satisfaction and OCB. It can be concluded that if management of organizations wants to have higher level of organizational citizenship behavior of their employees they have to satisfy them and they have to provide more benefits in shape of pay, promotion opportunities, supervisor's support and better relation with coworkers. Simply it is quite important to be good at given facets of job to get higher degree of satisfaction and OCB.

Future Implementations and Limitations: This study can be applied in banking sector of Pakistan as this identifies how women employees can be satisfied by offering better pay, promotion opportunities, support from supervisors and support from co-workers. The findings prove that these variables are equally important for both satisfaction and OCB of women employees. This study is with some limitations, as it considers banks only from the city of Lahore. Branches operating in other cities can be takes as sample to generalize the study. Similarly, onlys 8 banks are selected for study; if more banks are selected then study would be more generalized.

\section{References}

Balser, D. B. \& Harris, M. M. (2008). Factors Affecting Employee Satisfaction with Disability Accommodation: A Field Study. Employ Respons Rights, 20 (10), 13-28.

Bergeron, D. M., Shipp, A. J., Rosen, B. \& Furst, S. A. (2011). Organizational Citizenship Behavior and Career Outcomes: The Cost of Being a Good Citizen. Journal of Management.1-27,ISSN: 01492063, DOI: $10.1177 / 0149206311407508$.

Brower, H. H., Lester, S. W., Korsgaard, M. A. \& Dineen, B. R. (2009). A Closer Look at Trust Between Managers and Subordinates: Understanding the Effects of Both Trusting and Being Trusted on Subordinate Outcomes. Journal of Management, 35 (2), 327-347.

Bowen, P. \& Cattell, K. (2008). Job satisfaction of South African quantity surveyors. Engineering, Construction and Architectural Management, 15 (3), 260-269.

Chen, Z. (2001). Further investigavtion of the outcomes of loyalty to supervisor job satisfaction and intention to stay. Journal of Managerial Psychology , 16 (8), 650-660.

Crossman, A. \& Zaki, B. A. (2003). Job satisfaction and employee performance of Lebanese banking staff. Journal of Managerial Psychology, 18 (4), 368-376.

Danish, R. Q. \& Usman, A. (2010). Impact of Reward and Recognition on Job Satisfaction and Motivation: An Empirical Study from Pakistan. International Journal of Business and Management , 5 (2), 159-167.

Donohue, S. M. \& Heywood, J. S. (2004). Job satisfaction and gender:an expanded specification from the NLSY. International Journal of Manpower, 25 (2), 211-234.

Eskildsen, J., Kristensen, K. \& Antvor, H. G. (2010). The relationship between job satisfaction and national culture. The TQM Journal, 22 (4), 369-378.

Farh, J. L., Earley, P. C. \& Lin, S. C. (1997). Impetus for Action: A Cultural Analysis of Justice and Organizational Citizenship Behavior in Chinese Society. Administrative Science Quarterly, 42 (3), 421-444.

Foote, D. A. \& Tang, T. L. P. (2008). Job satisfaction and organizational citizenship behavior (OCB): Does team commitment make a difference in self-directed teams. Management Decision , 46 (6), 933 - 947.

Gonza'lez, J. V. \& Garazo, T. G. (2006). Structural relationships between organizational service orientation, contact employee job satisfaction and citizenship behavior. International Journal of Service Industry Management, 17 (1), 23-50.

Herbohn, K. (2005). Job Satisfaction Dimensions in Public Accounting Practice. Accounting Research Journal, $18(2), 63-82$.

Hui, C., Lam, S. S. \& Law, K. K. (2000). Instrumental values of organizational citizenship behavior for promotion: A field quasi-experiment. Journal of Applied Psychology, 85 (5), 822-828. 
Igbaria, M. \& Guimaraes, T. (1993). Antecedents and Consequences of Job Satisfaction among Information Center Employees. Journal of Management Information Systems, 9 (4), 145-174.

Ismail, A., \& Zakaria, N. (2009). Relationship between Interactional Justice and Pay for performance as an antecedent of job satisfaction: an empirical study in Malaysia. International Journal of Business and Management, 4 (3), 190-199.

Kavanaugh, J., Duffy, J. A. \& Lilly, J. (2006). The relationship between job satisfaction and demographic variables for healthcare professionals. Management Research News, 29 (6), 304-325.

Kim, S. (2006). Public service motivation and organizational citizenship behavior in Korea. International Journal of Manpower, 27 (8), 722 - 740.

Konovsky, M. A., \& Pugh, S. D. (1994). Citizenship Behavior and Social Exchange. The Academy of Management Journal, 37 (3), 656-669.

Kwantes, C. T. (2009). Culture, job satisfaction and morganizational commitmentin India and United states. Journal of Indian Business Research, 1 (4), 196-212.

Lee, K. L. (2008). An Examination between the Relationships of Conflict Management Styles and Employees Satisfaction. International Journal of Business and Management, 3 (9), 11-25.

Lam, S. S., Chun, H. \& Law, K. S. (1999). Organizational citizenship behavior: Comparing perspectives of supervisors and subordinates across four international samples. Journal of Applied Psychology, 84 (4), 594-601.

Lok, P. \& Crawford, J. (2004). The effect of organisational culture and leadership style on job satisfaction and organisational commitment A cross-national comparison. Journal of Management Development, 4, 321-338.

Lund, D. B. (2003). Organizational culture and job satisfaction. Journal of Business and Industrial Marketing, 18 (3), 219-236.

Malik, M. E., Nawab, D. S., Naeem, B. \& Danish, R. Q. (2010). Job Satisfaction and Organizational Commitment of University Teachers in Public Sector of Pakistan. International Journal of Business and Management, 5 (6), 17-26.

Murphy, G., Athanasou, J. \& King, N. (2002). Job satisfaction and organizational citizenship behavior A study of A study of Australian human service Professionals. Journal of Managerial Psychology, 17 (4), 287-297.

Mustafa, Z. (2011, 04 28). Oppression of women workers. Retrieved from http://www.zubeidamustafa.com/oppression-of-women-workers

Okpara, J. 0. (2006). Gender and the relationship between perceived fairness in pay, promotion, and job satisfaction in a sub-Saharan African economy. Women in Management Review, 21 (3), 224-240.

Oshagbemi, T. (2003). Personal correlates of job satisfaction: empirical evidence from UK universities. International Journal of Social Economics, 30 (12), 1210-1232.

Oshagbemi, T. (2000). Satisfaction with co-workers' behaviour. Employee Relations, 22 (1), 88 - 106.

Robbins, S. P. \& Coulter, M. (2004). Management. Prentice Hall.

Smucker, M. K., Whisenant, W. A. \& Pedersen, P. M. (2003). An Investigation of Job Satisfaction and Female Sports Journalists. Sex Roles , 47 (7/8), 401-407.

Tepper, B. J. \& Taylor, E. C. (2002). Relationships among supervisors' and subordinates' procedural. In press amj , 1-28.

Williams, M. L., McDaniel, M. A. \& Nguyen, N. T. (2006). A meta-analysis of the antecedents and consequences of pay level satisfaction. Journal of Applied Psychology, 9 (2), 392-413. 